\title{
DIVERSIFIKASI OLAHAN HASIL IKAN DAN PENDAMPINGAN: DAMPAKNYA TERHADAP MINAT BERWIRAUSAHA MASYARAKAT DESA
}

\author{
Teni Novianti ${ }^{1}$, Gita Erlangga Kurniawan ${ }^{2}$ \\ Universitas Nahdlatul Ulama Cirebon, Jalan Sisingamangaraja No. 33 Cirebon 45112, Jawa Barat, \\ Indonesia, gitaerlanggakurniawan15@yahoo.com
}

Diterima 31 Januari 2020, disetujui 28 September 2020, diterbitkan 29 Oktober2020

Pengutipan: Novianti, T \& Kurniawan, G.E. (2020). Diversifikasi Olahan Hasil Ikan dan Pendampingan: Dampaknya terhadap Minat Berwirausaha Masyarakat Desa. Gema Wiralodra, Vol 11, No 2, Hal 200-217, Oktober 2020.

\begin{abstract}
ABSTRAK
Penelitian ini bertujuan untuk mengetahui pengaruh pelatihan keterampilan diversifikasi olahan hasil ikan dan pembinaan masyarakat terhadap peningkatan minat berwirausaha. Penelitian ini merupakan bagian dari penelitian lapangan dengan pendekatan deksriptif kuantitatif. Sampel dalam penelitian ini yakni masyarakat produktif di Desa Randegan Kulon Kecamatan Jatitujuh, Kabupaten Majalengka yang mengikuti kegiatan pelatihan dan pembinaan diversifikasi olahan hasil ikan diselenggarakan oleh Fakultas Teknologi Kelautan dan Perikanan, Universitas Nahdlatul Ulama Cirebon bekerjasama dengan Penyuluh Perikanan Wilayah Kecamatan Jatitujuh Kabupaten Majalengka. Adapun jumlah sampel dalam penelitian ini adalah sebanyak 50 orang responden. Teknik pengumpulan data penelitian menggunakan instrumen kuesioner, wawancara dan observasi sedangkan analisis data menggunakan analisis regresi linier berganda dengan bantuan SPSS versi 20. Hasil pengujian hipotesis menunjukkan bahwa pelatihan diversifikasi olahan hasil ikan dan pembinaan masyarakat berpengaruh signifikan terhadap minat berwirausaha pada masyarakat di Desa Randegan Kulon Kecamatan Jatitujuh, Kabupaten Majalengka dengan nilai Signifikasi $0,000<0,05$ dan nilai koefisien determinasi yang menyatakan bahwa variabel bebas mempengaruhi variabel terikat sebesar 0,847 atau sama dengan $84,7 \%$ dan sisanya sebesar $15,3 \%$ dipengaruhi faktor lain yang tidak diteliti dalam penelitian ini. Hasil penelitian ini memberikan implikasi bahwa pelatihan dan pendampingan dalam meningkatkan keterampilan dalam berwirausaha perlu dilakukan untuk menggiatkan minat berwirausaha masyarakat desa.
\end{abstract}

Kata Kunci: Diversifikasi Olahan Hasil Ikan, Pendampingan, Minat Berwirausaha, Masyarakat Desa

\begin{abstract}
This study aims to determine the effect of skill training on diversification of processed fish products and community guidance on increasing interest in entrepreneurship. This research is field research with a quantitative descriptive approach. The sample in this study were productive communities in Randegan Kulon Village, Jatit Tujuh Subdistrict, Majalengka Regency, who participated in training activities and fostering diversification of processed products organized by the Faculty of Marine and Fisheries Technology, Cirebon Nahdlatul Ulama University in collaboration with the Regional Fisheries Extension Officer, Jatit Tujuh District, Majalengka Regency. The number of samples in this study was 50 respondents. The research data collection techniques used questionnaires, interviews, and observation instruments while data analysis used multiple linear regression analysis with the help of SPSS version 20. The results of hypothesis testing showed that training on diversification of processed fish products and community development had a significant effect on the interest in entrepreneurship in the community in Randegan Kulon Village, Kecamatan Jati Tujuh Majalengka Regency with a significance value of
\end{abstract}

Diterbitkan oleh: 
$0.000<0.05$ and a coefficient of determination which stated that the independent variable affected the dependent variable by 0.847 or equal to $84.7 \%$ and the remaining $15.3 \%$ was influenced by other factors not examined in this study. The results of this study imply that training and mentoring in improving skills in entrepreneurship need to be carried out to increase the interest in entrepreneurship in rural communities.

Keywords: Diversification of Processed Fish Products, Assistance, Entrepreneurial Interest, Village Community

\section{PENDAHULUAN}

Pembangunan sumber daya manusia perlu dilaksanakan secara menyeluruh, terarah, dan terpadu di berbagai bidang, terutama yang mencakup bidang pendidikan, latihan, serta penyediaan lapangan kerja. Program sumber daya manusia pada dasarnya diarahkan agar manusia mampu beradaptasi dengan lingkungan serta mampu aktif mengeksplorasi lingkungan. Pengembangan kemampuan intelektual, keterampilan dan kreativitas sangat diperlukan, sehingga mereka mempunyai keyakinan diri besar, mampu mandiri dan selalu berupaya meningkatkan etos kerja yang selanjutnya mereka dapat memperoleh kesempatan kerja atau membuka usaha sendiri (Irawati, 2018).

Wirausaha mempunyai kaitan yang sangat erat dengan pertumbuhan ekonomi nasional. Menurut Frinces (2010), seorang wirausaha sangat diperlukan karena perannya di dalam mendinamisasikan kegiatan ekonomi bisnis keluarga, masyarakat, daerah danNegara. Bila dinamisasi kegiatan ekonomi bisnis ini dapat dipertahankan danbahkan ditingkatkan dalam waktu yang cukup lama, maka hal ini akan dapatmembuat fondasi yang kuat bagi ketahanan ekonomi negara terhadapfluktuasi dan krisis ekonomi global. Oleh karena itu seorang wirausaha selain harus memiliki inovasi dan kreativitas tetapi juga harus mempunyai kinerja yang baik agar barang atau jasa yang diproduksinya bermanfaat bagi orang lain dan secara khusus membantu pertumbuhan ekonomi nasional.

Kewirausahaan mampu membuat suatu negara menjadi maju dan makmur karenakewirausahaan sebagai pencipta kesempatankerja baru, penghasilan baru, inovasi baru, sertaunggul dalam kualitas untuk mengorganisirsumberdaya yang diperlukan dalammenciptakan nilai tambah. Nilai tambahtersebut dapat diciptakan dengan caramengembangkan teknologi baru, perbaikan produk (barang dan jasa) yang sudah ada serta menemukanpengetahuan baru, menemukan cara baru untukmenghasilkan barang dan

Diterbitkan oleh:

Universitas Wiralodra

Jln. Ir. H. Juanda Km 3 Indramayu, Jawa Barat 
jasa yang baru yanglebih efisien dan secara keseluruhan disebutsebagai sumber pertumbuhan ekonomi danpembangunan ekonomi (Rusdiana, 2018).

Ditinjau dari kemandirian ekonomi, berwirausaha akan memberikan peluang untuk diri sendiri dalam mencapai kesuksesan. Dari segi sosial akan memberikan peluang kerja bagiorang lain, lingkungan dan masyarakat. Frinces (2016) menyebutkan bahwa menjadi wirausaha bukan sebagai alternatif profesi, tetapi menjadi wirausaha adalah sebuah pilihan strategis yangharus dibuat dengan tekad yang bulat dan kuat. Pada kondisi sekarang ini dapat dikatakan bahwa kunci kemakmuran adalah wirausaha. Wirausaha adalah sebuah profesi yang sangat menjanjikan bagi kebaikan dalam kualitas hidup denganmeningkatkan daya beli. Daya beli tercipta dengan tingginya pendapatan yangdiperoleh sebagai akibat dari profesi yang ditekuni.

Suatu negara akan mencapai tingkat kemakmuran apabila jumlah entrepreneurnya paling sedikit $2 \%$ dari total jumlah penduduknya, sedangkan di Indonesia diperkirakan keberadaannya baru sekitar $0,24 \%$. Jumlah itu lebih rendah dibandingkan dengan jumlah wirausaha di beberapa negara luar yang tingkat pertumbuhan ekonominya tinggi. Jumlah wirausaha di Amerika Serikat sekitar $11 \%$, di Singapura mencapai $7 \%$ dan di Malaysia mencapai $5 \%$ (Munawaroh et al.,2016; Rusdiana 2018).

Melihat perbandingan jumlah wirausaha di negara maju dengan jumlah wirausaha di Indonesia, maka jumlah wirausaha di Indonesia masih perlu ditingkatkan dengan mengembangkan sektor kewirausahaan dan mendorong masyarakat menjadi wirausaha dalam mendukung ekonomi negara menuju kemandirian bangsa.Sukirman (2017) menyebutkan bahwa untuk mencapai pertumbuhan ekonomi di Indonesia dalam ketidakpastian global maka perlu melakukan pemberdayaan usaha kecil yang dianggap mampu mengembangkan produksi. Sesuai dengan program pemerintah ditargetkan 5 juta wirausaha baru sampai dengan Tahun 2025 dengan mengembangkan sumber daya manusia untuk kemajuan wirausaha nasional.

Pemerintah Indonesia sedang berfokus meningkatkan jumlah wirausaha agar dapat berperan dalam mendukung ekonomi negara agar lebih maju pada masa mendatang. Saat ini Pemerintah tingkat nasional ataupun daerah terus mengembangkan program wirausaha produktif tujuannya adalah untuk menumbuhkan wirausahawan baru dan meningkatkan

Diterbitkan oleh: 
lapangan usaha. Ditingkat nasional sendiri sangat banyak kementerian yang mengembangkan konsep dan program kewirausahaan, seperti Kementerian Ketenagakerjana (Kemnaker) RI yang mengadakan program gerakan penciptaan wirausaha baru nasional. Selain itu, Kementerian Kelautan dan Perikanan RI sedang gencar melakukan Pendampingan Penumbuh dan Pengembangan Kelembagaan Pelaku Utama Perikanan sebagai langkah awal untuk memanfaatkan potensi yang dimiliki daerah tersebut untuk dibina dan dikembangkan kegiatan usahanya dalam meningkatkan kesejahteraan ekonomi masyarakat berdasarkan Keputusan Menteri Kelautan dan Perikanan RI Nomor KEP.14/MEN/2012.

Salah satu Desa di Kabupaten Majalengka adalah Desa Randegan Kulon terletak di bagian timur Kecamatan Jatitijuh. Penghasilan warga rata-rata dari pertaniansekitar 77,04 $\%$ dengan profesi sebagai petani $43,18 \%$, buruh tani sebanyak 33,86\% dan terdapat sekitar 16,42\% sebagai pedagang. Sedangkan sisanya sekitar $6,54 \%$ bekerja sebagai nelayan dan karyawan (Data Profil Desa Randegan Kulon Tahun 2019). Masih kurangnya masyarakat di Desa Randegan Kulon yang berwirausahamendorong adanya upaya untuk meningkatkan minat masyarakat khususnya yang akan mengembangkan potensi perikanan karena di desa sekitar terdapat pusat produksi ikan pindang dengan bahan baku berasal dari ikan laut seperti deles, salem dan kembung (Data Laporan Tahunan Dinas Pertanian dan Perikanan Kabupaten Maajalengka Tahun 2018).

Untuk menumbuhkembangkan minat masyarakat di Desa Randegan Kulon dalam berwirausaha makadibutuhkan pelatihan dan pembinaan. Menurut Irawati(2018), pelatihan merupakan proses pendidikan jangka pendek yangmenggunakan prosedur sistematis danterorganisir sehingga tenaga kerja nonmanajerial mempelajari pengetahuan danketrampilan teknis untuk tujuan tertentu.Pembinaan juga memiliki arti penting dalam mengembangkan usaha kecil. Pembinaan merupakan proses atau pengembangan yang mencakup urutan-urutan pengertian, diawali dengan mendirikan, menumbuhkan, memelihara pertumbuhan tersebut yang disertai usaha-usaha perbaikan, menyempurnakan dan mengembangkannya (Alhempi dan Harianto, 2013). Sasaran dari pelatihan diversifikasi olahan hasil ikan dan pembinaan masyarakat adalah untuk menumbuhkembangkan minat masyarakat dalam berwirausaha di bidang olahan hasil ikan

Diterbitkan oleh: 
seperti inovasi dalam pengolahan bahan baku ikan salem, kembung dan deles yang biasa di buat ikan pindang dapat diolah menjadiproduk lain seperti penyedap rasa dari daging ikan, nugget ikan dan bakso ikan. Oleh karena ituagar selaras dengan sasaran tersebut maka Fakultas Teknologi Kelautan dan Perikanan Universitas Nahdlatul Ulama Cirebon bersinergi dengan Penyuluh Perikanan Wilayah Kecamatan Jatitujuh, Kabupaten Majalengka sebagai upaya untuk membentuk jiwa wirausaha bagi masyarakat Desa Randegan Kulon dengan melakukan pelatihan keterampilan diversifikasi olahan hasil ikan dan pembinaan masyarakat sesuai dengan potensi alam yang ada di Desa Randegan Kulon. Melalui kegiatan peningkatan keterampilan dan pembinaan ini minat kewirausahaan masyarakat Desa Randegan Kulon dibangkitkan, untuk kemudian diarahkan menuju pengembangan pengelolaan usaha-usaha ekonomi sehingga dapat meningkatkan perekonomian masyarakat desa tersebut.

Tujuan penelitian ini adalah mengetahui secara empirik pengaruh pelatihan diversifikasi olahan hasil ikan dan pembinaan masyarakat terhadap peningkatan minat berwirausaha di Desa Randegan Kulon Kecamatan Jatitijuh, Kabupaten Majalengka, dan besarnya peningkatan minat berwirausaha pada masyarakat di Desa Randegan Kulon Kecamatan Jatitijuh, Kabupaten Majalengka karena pengaruh pelatihan diversifikasi olahan hasil ikan dan pembinaan masyarakat.

\section{METODE PENELITIAN}

\section{Lokasi dan Jenis Penelitian}

Penelitian dilakukan di Desa Randegan Kulon Kecamatan, Jatitujuh Kabupaten Majalengka. Penelitian ini dirancang menggunakan metode penelitian lapangan dengan pendekatan deskriptif kuantitatif. Dimana penulis ingin mengetahui apakah pelatihan diversifikasi olahan hasil ikan $\left(\mathrm{X}_{1}\right)$ dan pembinaan masyarakat $\left(\mathrm{X}_{2}\right)$ berpengaruh terhadap minat berwirausaha $(\mathrm{Y})$.

\section{Sampel Penelitian}

Sampel penelitian ini adalah masyarakat produktif berdomisili di Desa Randegan Kulon Kecamatan Jatitujuh, Kabupaten Majalengka yang mengikuti pelatihan keterampilan diversifikasi olahan hasil ikan dan pembinaan masyarakat yang dilaksanakan oleh Universitas Nahdlatul Ulama Cirebon bekerjasama dengan Penyuluh Perikanan

Diterbitkan oleh: 
Wilayah Kecamatan Jatitujuh, Kabupaten Majalengka dengan jumlah peserta pelatihan dan pembinaan sebanyak 50 orang nelayan yang menengah ke bawah

\section{Teknik Pengumpulan Data}

Metode yang digunakan untukmengumpulkan data dalam penelitian iniadalah metode angket (instrumen kuesioner), wawancara dan observasi. Menurut Sugiyono (2013), metode pengumpulan data tersebut digunakan karena ingin mendapatkan data yang lengkap, akurat dan konsisten. Pada penelitian ini, angket atau kuesioner yang digunakan adalah angket tertutup yang berbentuk checklist. Dimana dalam angket tersebut terdapat sederet pertanyaan dan responden tinggal membubuhkan tanda centang $(\sqrt{ })$ pada kolom yang sesuai dengan pendapat responden. Adapun pengukuran menggunakan Skala Likert dengan ketentuan: (1) Skor 1 "Sangat tidak setuju”, (2) Skor 2 "Tidak setuju”, (3) Skor 3 "Cukup setuju", (4) Skor 4 "Setuju”, dan (5) Skor 5 "Sangat setuju" (Sugiyono, 2013). Sedangkan wawancara dan observasi merupakan teknik pengamatan dilapangan pada objek penelitian untuk mengetahui hal-hal dari responden yang lebih mendalam dan mendapatkan data awal sehingga mengetahui bagaimana minat berwirausaha masyarakat yang telah mengikuti pelatihan diversifikasi olahan ikan dan pembinaan.

\section{Definisi Variabel dan Insturmen Penelitian}

Instrumen yang digunakan pada penelitian ini terdiri dari Kuesioner pelatihan diversifikasi olahan hasil ikan $\left(\mathrm{X}_{1}\right)$, pembinaan masyarakat $\left(\mathrm{X}_{2}\right)$ dan minat berwirausaha (Y). Variabel pelatihan diversifikasi olahan hasil ikan $\left(\mathrm{X}_{1}\right)$ yaitu bagian dari suatu proses pendidikan yang tujuannya untuk meningkatkan kemampuan atau memperoleh keterampilan khusus dibidang olahan ikan bagi seseorang atau sekelompok orang. Adapun item-item yang disusun sebagai berikut: pelatih (trainer), materi pelatihan, metode pelatihan, fasilitas pelatihan, lama pelatihan, dan tujuan pelatihan dan antusias peserta dalam mengikuti pelatihan. Variabel pembinaan masyarakat $\left(\mathrm{X}_{2}\right)$ yaitu upaya yang dilakukan pemerintah dan perguruan tinggi (akademisi) kepada masyarakat melalui pemberian bimbingan atau pendampingan dan penyuluhan untuk menumbuhkan dan meningkatkan kemampuan usaha masyarakat agar menjadi usaha produktif yang tangguh dan mandiri serta dapat berkembang menjadi usaha kecil dan menengah. Adapun itemitemnya sebagai berikut: penyediaan tenaga konsultan profesional, penyediaan sarana,

Diterbitkan oleh:

Universitas Wiralodra

Jln. Ir. H. Juanda Km 3 Indramayu, Jawa Barat 
prasarana, teknologi dan informasi, pendampingan akses perizinan usaha, pendampinganakses permodalan, pendampingan akses promosi serta pendampingan akses pemasaran dan pengembangan kemitraan.Variabel minat berwirausaha (Y) adalah keyakinan,keinginan, rasa percaya dalam diri seseorang dan kemampuan untuk menjadi wirausaha sehingga mendorong seseorang untuk berkreatifitas dan beraktivitas dengan membuka usaha. Adapun aspek-aspek pengukuran variabel minat berwirausaha yaitu ketertarikan, keinginan, keyakinan, kemampuan, kebutuhan, pengalamandan usaha untuk mewujudkannya.

\section{Teknik Analisis Data}

Teknik analisis data menggunakan beberapa pengujian diantaranya yaitu pengujian kualitas data (uji validitas data, uji realibilitas data, uji normalitas data dan uji homogenitas data) dan pengujian hipotesis (uji F dan koefisien determinasi).

\section{Pengujian Kualitas Data}

a) Uji Validitas Data

Uji validitas digunakan untuk melihat kevalidan alat ukur yang digunakan dalam penelitian untuk melihat kevalidannya dapat menggunakan teknikkorelasiPearson Product Moment, yaitumencarikorelasiantaraskor item denganskor total. Dengan kriteria pengujian sebagai berikut: data dikatakan valid, jika $r$ hitung > $r$ tabel, dan data dikatakan tidak valid, jika $r$ hitung < r tabel (Sujarweni, 2015).

b) Uji Reliabilitas Data

Suatu instrumen dikatakan Reliabel apabila jawaban seseorang (responden) terhadap pertanyaan/pernyataan yang diajukan konsisten atau stabil dari waktu ke waktu.Dalam menjawab instrumen yang reliabel, maka peneliti menguji dengan metode koefisien Cronbach alpha. Dengan ketentuan reliabel, jika angka Cronbach alpha> 0,60 (Sujarweni, 2015).

\section{c) Uji Normalitas Data}

Uji normalitas data digunakan untuk melihat dalam model regresi, variabel dependen dan independennya memiliki distribusi normal atau tidak.Untuk mengujinya digunakan Kolmomogorov-Sminorv. Untuk menentukan normalitas digunakan pedoman sebagai berikut: Jika Sig > 0,05, maka sampel berasal dari populasi yang berdistribusi normal.

Diterbitkan oleh: 
Jika Sig $<0,05$, maka sampel bukan berasal dari populasi yang berdistribusi normal (Sujarweni, 2015)

d) Uji Homogenitas Data

Uji Homogenitas data ini dilakukan untuk menentukan apakah varian dari sampel itu sama atau tidak. Untuk menguji sampel sama atau tidak menggunakan Levene test dengan pedoman sebagai berikut : Jika Sig > 0,05, maka variansi setiap sampel sama (homogen). Jika Sig < 0,05, maka variansi setiap sampel tidak sama atau tidak homogen (Sujarweni, 2015)

\section{Pengujian Hipotesis}

a) Model Regresi Linier Berganda

Analisis data pada rumusan masalah yang diteliti menggunakan teknik analisis regresi linear berganda untuk mengukur pengaruh antara dua variabel independen yaitu pelatihan diversifikasi olahan hasil ikan $\left(\mathrm{X}_{1}\right)$ dan pembinaan masyarakat $\left(\mathrm{X}_{2}\right)$ terhadap minat berwirausaha di Desa Randegan Kulon Kecamatan Jatitujuh, Kabupaten Majalengka (Y) sebagai variabel dependen. Adapun bentuk persamaan dari variabel tersebut adalah sebagai berikut :

$$
Y=a+b_{1} X_{1}+b_{2} X_{2}
$$

Keterangan :

$\mathrm{Y}=$ Minat Berwirausaha

$\mathrm{a}=$ Nilai Konstanta harga $\mathrm{Y}$ jika $\mathrm{X}=0$

$\mathrm{b}_{1}=$ Koefisien Regresi $\mathrm{X}_{1}$

$\mathrm{b}_{2}=$ Koefisien Regresi $\mathrm{X}_{2}$

$\mathrm{X}_{1}=$ Pelatihan Diversifikasi Olahan Ikan

$\mathrm{X}_{2}=$ Pembinaan Masyarakat

b) Uji F

Uji statistik F digunakan untuk mengetahui pengaruh antara variabel independen secara simultan terhadap variabel dependen (Sugiyono, 2013).

Hipotesis yang diuji pada penelitian ini adalah :

Diterbitkan oleh: 
$\mathrm{H}_{0}: \rho_{\mathrm{Y}} \mathrm{X}_{1} \mathrm{X}=0$ : Pelatihan diversifikasi olahan hasil ikan dan pembinaan masyarakat tidak berpengaruh positif terhadap minat berwirausaha di Desa Randegan Kulon Kecamatan Jatitujuh, Kabupaten Majalengka;

$\mathrm{H}_{1}$ : $\rho_{Y X 1 \times 2 .>} 0$ : Pelatihan diversifikasi olahan hasilikan dan pembinaan masyarakat berpengaruh positif terhadap minat berwirausaha di Desa Randegan Kulon Kecamatan Jatitujuh, Kabupaten Majalengka.

c) Koefisien determinasi $\mathrm{R}^{2}$

Koefisien determinasi $\left(\mathrm{R}^{2}\right)$ bertujuan untuk mengetahui persentase sumbangan pengaruh variabel independen $\left(\mathrm{X}_{1}, \mathrm{X}_{2}, \ldots \ldots . \mathrm{Xn}\right)$ secara serentak terhadap variabel dependen $(\mathrm{Y})$. Koefisien ini menunjukan ampai seberapa besar persentase variabel independen yang digunakan dalam model mampu menjelaskan variasi variabel dependen. Nilai $\mathrm{R}^{2}$ mempunyai range antara $0-1$, jika nilai range semakin mendekati angka 1 maka maka persentase sumbangan pengaruh yang diberikan variabel independen terhadap variabel dependen adalah mendekati sempurna atau variasi variabel independen yang digunakan dalam model menjelaskanvariasivariabeldependen (Sujarweni, 2015). Adapun dalam proses pengolahan datanya menggunakan bantuan perangkat lunak (software) statistik SPSS 20.0 for window maka dalam output SPSS, koefisien determinasi terletak pada tabe Model Summary ${ }^{b}$ dan tertulis $R$ Squuare.

\section{HASIL PENELITIAN DAN PEMBAHASAN}

\section{Uji Validitas dan Reliabilitas}

Uji validitas digunakan untuk mengetahui seberapa cermat suatu tes melakukan fungsiukurnya. Adapun hasil uji validitas dapat dilihatpada tabel di bawah ini.

Tabel 1. Uji Validitas

\begin{tabular}{|c|c|c|c|c|}
\hline No & Item & $\mathbf{r}_{\text {hitung }}$ & $\mathbf{r}_{\text {tabel }}$ & Ket \\
\hline 1. & $\mathrm{X}_{1} .1$ & 0,421 & 0,279 & Valid \\
\hline 2. & $\mathrm{X}_{1} .2$ & 0,511 & 0,279 & Valid \\
\hline 3. & $\mathrm{X}_{1} \cdot 3$ & 0,333 & 0,279 & Valid \\
\hline 4. & $\mathrm{X}_{1} .4$ & 0,409 & 0,279 & Valid \\
\hline 5. & $\mathrm{X}_{1} .5$ & 0,380 & 0,279 & Valid \\
\hline 6. & $\mathrm{X}_{1} .6$ & 0,446 & 0,279 & Valid \\
\hline 7. & $\mathrm{X}_{1} .7$ & 0,568 & 0,279 & Valid \\
\hline 8. & $\mathrm{X}_{1} .8$ & 0,597 & 0,279 & Valid \\
\hline 9. & $\mathrm{X}_{2} .1$ & 0,436 & 0,279 & Valid \\
\hline
\end{tabular}

\begin{tabular}{|c|c|c|c|c|}
\hline No & Item & $\mathbf{r}_{\text {hitung }}$ & $\mathbf{r}_{\text {tabel }}$ & Ket \\
\hline 17. & Y.1 & 0,566 & 0,279 & Valid \\
\hline 18. & Y.2 & 0,430 & 0,279 & Valid \\
\hline 19. & Y.3 & 0,549 & 0,279 & Valid \\
\hline 20. & Y.4 & 0,468 & 0,279 & Valid \\
\hline 21. & Y.5 & 0,484 & 0,279 & Valid \\
\hline 22. & Y.6 & 0,497 & 0,279 & Valid \\
\hline 23. & Y.7 & 0,333 & 0,279 & Valid \\
\hline 24. & Y.8 & 0,647 & 0,279 & Valid \\
\hline 25. & Y.9 & 0,511 & 0,279 & Valid \\
\hline
\end{tabular}




\begin{tabular}{|c|c|c|c|c|}
\hline 10. & $\mathrm{X}_{2} \cdot 2$ & 0,525 & 0,279 & Valid \\
\hline 11. & $\mathrm{X}_{2} \cdot 3$ & 0,378 & 0,279 & Valid \\
\hline 12. & $\mathrm{X}_{2} .4$ & 0,480 & 0,279 & Valid \\
\hline 13. & $\mathrm{X}_{2} .5$ & 0,459 & 0,279 & Valid \\
\hline 14. & $\mathrm{X}_{2} \cdot 6$ & 0,312 & 0,279 & Valid \\
\hline 15 & $\mathrm{X}_{2} .7$ & 0,579 & 0,279 & Valid \\
\hline 16. & $\mathrm{X}_{2} .8$ & 0,416 & 0,279 & Valid \\
\hline
\end{tabular}

\begin{tabular}{|c|c|c|c|c|}
\hline 26. & Y.10 & 0,601 & 0,279 & Valid \\
\hline 27. & Y.11 & 0,571 & 0,279 & Valid \\
\hline
\end{tabular}

Sumber : Hasil Pengolahan Data Penelitian Novianti, 2019.

Dari tabel di atas diketahui bahwa nilai $r$ hitung $>r$ tabel sehingga semua item variabel dinyatakan valid.

Uji Reliabilitas adalah tingkat keandalankuesioner harus reliabel atau ketepatan, apabiladicobakan secara berulang-ulang kepadakelompok yang sama akan menghasilkan data yang sama. Adapun hasil uji reliabilitas dapatdilihat pada tabel di bawah ini:

Tabel 2. Uji Reliabilitas

\begin{tabular}{|c|c|c|c|}
\hline Variabel & $\begin{array}{c}\text { Reliabilitas Instrumen/ } \\
\text { Koefisien Alfa }\left(\mathrm{r}_{\text {hitung }}\right)\end{array}$ & Keterangan & $\begin{array}{l}\text { Kategori Nilai Reliabilitas } \\
\text { Instrumen/Koefisien Alfa }\end{array}$ \\
\hline $\mathrm{X}_{1}$ & 0,689 & Reliabel & Kuat \\
\hline $\mathrm{X}_{2}$ & 0,632 & Reliabel & Kuat \\
\hline $\mathrm{Y}$ & 0,653 & Reliabel & Kuat \\
\hline
\end{tabular}

Sumber : Hasil Pengolahan Data Penelitian Novianti, 2019.

Dari tabel di atas diketahui bahwa semua nilai Cronbach's Alfa $>0,5$.berarti seluruh itemvariabel penelitian semuanya reliable dan dapatdilanjutkan ke uji berikutnya.

Uji Normalitas dan Uji Homogenitas

Pengujian normalitas yang digunakan adalah teknik Kolmogorov-Smirnov dengan ketentuan Jika nilai Sig > 0,05, maka sampel berasal dari populasi yang berdistribusi normal. Data hasil uji normalitas direkap pada tabel 3.

Tabel 3. Uji Normalitas

\begin{tabular}{|l|l|l|l|l|l|l|}
\hline & \multicolumn{5}{|l|}{ Kolmogorov-Smirnov $^{\mathrm{a}}$} & \multicolumn{4}{l|}{ Shapiro-Wilk } \\
\cline { 2 - 7 } & Statistic & $\mathrm{df}$ & Sig. & Statistic & Df & Sig. \\
\hline X1.PELATIHAN & .118 & 50 & .060 & .967 & 50 & .177 \\
X2.PEMBINAAN & .115 & 50 & .099 & .969 & 50 & .208 \\
Y.MINAT & .113 & 50 & .146 & .974 & 50 & .335 \\
\hline
\end{tabular}

a. Lilliefors Significance Correction

Berdasarkan tabel 3 di atas, hasil uji normalitas dengan Kolmogorov-Smirnov dapat diketahui bahwa nilai probabilitas signifikansi (sig.) dari seluruh variabel penelitian ini lebih besar dari 0,05, maka dapat disimpulkan bahwa data tersebut berdistribusi normal. 
Tabel 4. Uji Homogenitas

Dependent Variable:Y.Minat Berwirausaha

\begin{tabular}{|c|c|c|c|}
\hline $\mathrm{F}$ & df1 & df2 & Sig. \\
\hline 1.420 & 41 & 8 & \\
\hline & & & 314 \\
\hline
\end{tabular}

Berdasarkan tabel 4 di atas, hasil uji homogenitas dengan menggunakan Levene test dapat diketahui bahwa nilai probabilitas signifikansi (sig.) dari seluruh variabel dalam penelitian ini lebih besar dari 0,05 , ini berarti bahwa seluruh variabel bersifat homogen atau varians populasi adalah identik.

\section{Uji Regresi Berganda}

\section{Tabel 5. Uji Regresi Berganda}

\begin{tabular}{|l|c|c|c|c|c|}
\hline & & & Model Summary \\
Model & $\mathrm{R}$ & R Square & $\begin{array}{c}\text { Adjusted R } \\
\text { Square }\end{array}$ & $\begin{array}{c}\text { Std. Error of } \\
\text { the Estimate }\end{array}$ & Durbin-Watson \\
\hline 1 & $.873^{\mathrm{a}}$ & .847 & .845 & .766 & 2.515 \\
\hline
\end{tabular}

a. Predictors: (Constant), X2.Pembinaan, X1.Pelatihan

b. Dependent Variable: Y.Minat Berwirausaha

Coefficients $^{\mathrm{a}}$

\begin{tabular}{|c|c|c|c|c|c|c|c|c|}
\hline \multirow{2}{*}{\multicolumn{2}{|c|}{ Model }} & \multicolumn{2}{|c|}{$\begin{array}{c}\text { Unstandardized } \\
\text { Coefficients }\end{array}$} & \multirow{2}{*}{\begin{tabular}{|c|}
$\begin{array}{c}\text { Standardized } \\
\text { Coefficients }\end{array}$ \\
Beta \\
\end{tabular}} & \multirow[b]{2}{*}{$\mathrm{t}$} & \multirow[b]{2}{*}{ Sig. } & \multicolumn{2}{|c|}{ Collinearity Statistics } \\
\hline & & B & Std. Error & & & & Tolerance & VIF \\
\hline \multirow[t]{3}{*}{1} & (Constant) & 10.640 & 1.093 & & 9.738 & .000 & & \\
\hline & X1.Pelatihan & .730 & .039 & .652 & 17.321 & .004 & .492 & 2.031 \\
\hline & X2.Pembinaan & .934 & .046 & .969 & 20.283 & .000 & .492 & 2.031 \\
\hline
\end{tabular}

a. Dependent Variable: Y.Minat Berwirausaha

Sumber : Hasil Pengolahan Data Penelitian Novianti, 2019.

Tabel5 di atas merupakan Coefficient variabel pelatihan diversifikasi olahan hasil ikan $\left(\mathrm{X}_{1}\right)$, pembinaan masyarakat $\left(\mathrm{X}_{2}\right)$ danminat berwirausaha $(\mathrm{Y})$ yang menggambarkan bahwa persamaan regresi ganda adalah sebagai berikut:

$$
\begin{aligned}
& Y=a+b_{1} X_{1}+b_{2} X_{2} \\
& Y=10,640+0,730 X_{1}+0,934 X_{2}
\end{aligned}
$$


Selanjutnya dari Model Summary diketahui bahwa nilai Rsebesar 0,873 menunjukkan bahwa terdapat hubungan yang sangat kuat antara pelatihan danpembinaan terhadap minat berwirausaha, karena angkanya mendekati 1.Sedangkan Koefisien Determinasi ( $R$ square) memiliki nilai sebesar 0,847 menunjukkan bahwa minat berwirausaha dijelaskanoleh pelatihan diversifikasi olahan hasil ikan dan pembinaan masyarakat sebesar $84,7 \%$, sedangkan sisanya dijelaskan oleh variabel lainyang tidak diteliti dalam penelitian ini. Dari uji ANOVA atau ujiF, didapatkan hasil F hitung sebesar 421,43 dengan nilai signifikasi sebesar 0,000. Hal ini menunjukkan bahwa secara simultan pelatihan diversifikasi olahan hasil ikandan pembinaan masyarakat memiliki pengaruhterhadap minat berwirausaha di Desa Randegan Kulon Kecamatan Jatitujuh Kabupaten Majalengka, berarti hipotesis satu $\left(\mathrm{H}_{1}\right)$ diterima.

\section{Pelatihan Diversifikasi Olahan Hasil Ikan dan Pembinaan Masyarakat Terhadap Minat Berwirausaha di Desa Randegan Kulon Kecamatan Jatitujuh Kabupaten Majalengka \\ Penelitian ini dilakukan dengan membagikan kuesioner, melakukan wawancara dan} observasi terhadap 50 orang masyarakat yang tinggal di Desa Randegan Kulon Kecamatan Jatitujuh, Kabupaten Majalengka. Berdasarkan hasil penelitian masyarakat yang menjadi responden sebagian besar berjenis kelamin perempuan yaitu sebanyak 45 orang (90\%) dan peserta laki-laki sebanyak 5 orang $(10 \%)$. Responden tersebut telah mengikuti kegiatan pelatihan diversifikasi olahan hasil ikan dan pembinaan masyarakat yang diselenggarakan oleh Fakultas Teknologi Kelautan dan Perikanan Universitas Nahdlatul Ulama Cirebon bekerjasama dengan Penyuluh Perikanan Wilayah Kecamatan Jatitujuh Kabupaten Majalengka.

Adapun data mengenai umur masyarakat yang menjadi responden dalam penelitian ini yaitu berumur 26-31 tahun sebanyak 22 orang dengan persentase $44 \%$, umur 32-37 tahun sebanyak 12 orang dengan persentase 24\%, umur 38-43 tahun sebanyak 8 orang dengan persentase $16 \%$, umur 44-49 sebanyak 2 orang dengan presentase $4 \%$, umur 50-55 tahun sebanyak 5 orang dengan persentase 10\% dan umur 56-61 tahun sebanyak 1 orang dengan persentase $2 \%$. Dengan demikian dapat disimpulkan bahwa masyarakat di Desa Randegan Kulon Kecamatan Jatitujuh Kabupaten Majalengka yang menjadi responden terbanyak adalah yang berusia 26-31 tahun.Diketahui bahwa peserta pelatihan yang

Diterbitkan oleh: 
terbanyak adalah berpendidikan tamat SMA yaitu sebanyak 20 orang (40\%). Minat berwirausaha diukur melalui aspek-aspeknya, yaitu ketertarikan, keinginan, keyakinan berkaitan dengan kewirausahaan, kemampuan, kebutuhan, pengalaman dan usaha untuk mewujudkannya. Hasil penelitian tentang minat berwirausaha dapat dilihat pada Gambar 1.

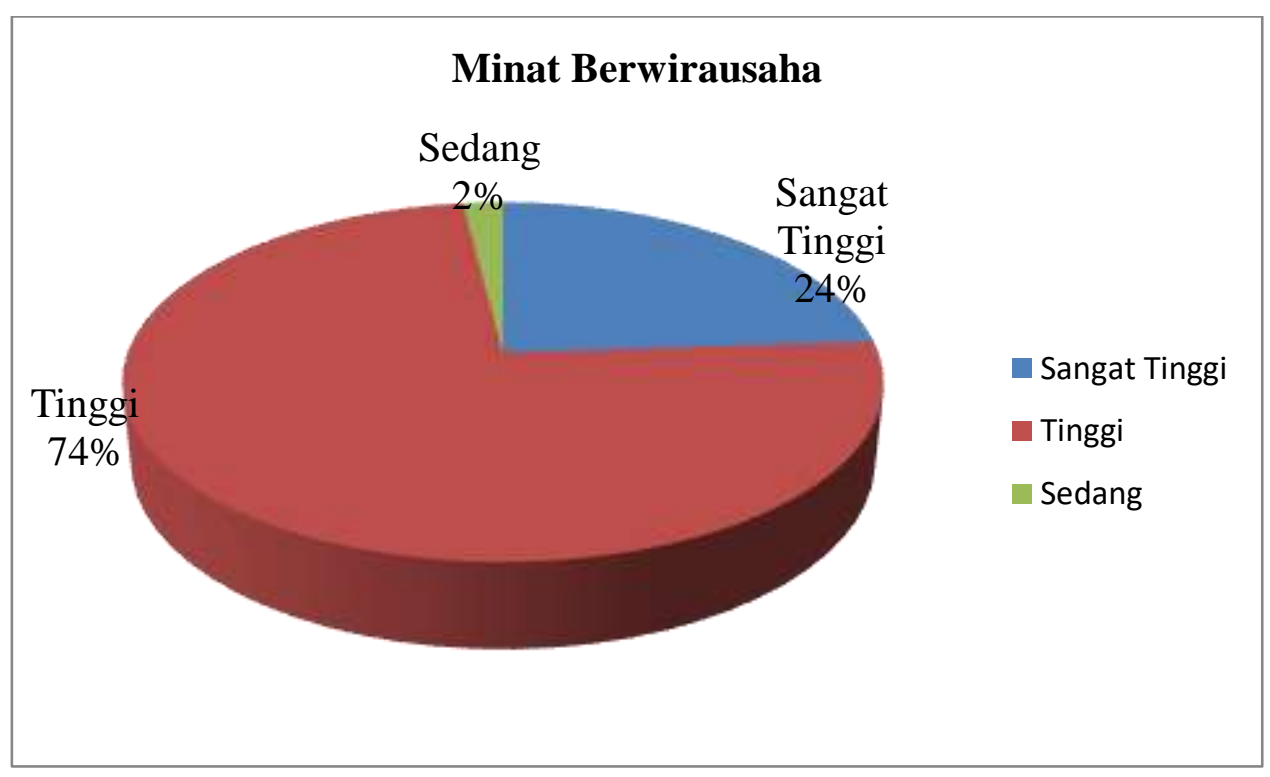

Gambar 1. Minat Berwirausaha Masyarakat di Desa Randegan Kulon Kecamatan

\section{Pembahasan} Jatitujuh Kabupaten Majalengka

Berdasarkan Gambar 1 diketahui bahwa responden memiliki minat yang tinggi untuk berwirausaha sebanyak 74\% setelah mengikuti kegiatan pelatihan diversifikasi olahan hasil ikan dan pembinaan masyarakat di Desa Randegan Kulon Kecamatan Jatitujuh, Kabupaten Majalengka.Kondisi ini menunjukkan bahwa pelatihan diversifikasi olahan hasil ikan dan pembinaan masyarakat yang dilakukan oleh Fakultas Teknologi Kelautan dan Perikanan Universitas Nahdlatul Ulama Cirebon dan Penyuluh Perikanan Kecamatan Jatitujuh, Kabupaten Majalengka mampu meningkatkan ketertarikan masyarakat produktif untuk melakukan kegiatan kewirausahaan. Secara umum minat berwirausaha masyarakat di Desa Randegan Kulon Kecamatan Jatitijuh, Kabupaten Majalengka ditunjukkan dengan adanya tumbuh rasa ketertarikan, keinginan, keyakinan dan adaya usaha-usaha untuk mewujudkan minat berwirausaha melalui ide-ide yang dimiliki untuk melakukan usaha dengan karakteristik kepribadiannya, berani mengambil resiko, siap mental, dapat menerima 
tantangan, percaya diri, mempunyai kekuatan usaha, kreatif dan inovatif serta mempunyai keterampilan dan adanya bimbingan untuk memenuhi kebutuhan.

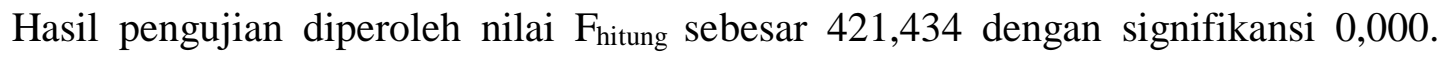
Dengan signifikansi 0,000 (kurang dari 0,05) ini sudah dapat dipastikan bahwa nilai $F_{\text {hitung }}$ akan lebih besar daripada $F_{\text {tabel. }}$. Dengan besarnya $F_{\text {hitung }}>F_{\text {tabel }}$ atau signifikan sinya kurang dari 0,05 maka hipotesis Ho ditolak dan $\mathrm{H}_{1}$ diterima, artinya variabel bebas secara bersamasama berpengaruh signifikan terhadap variabel terikat. Dengan demikian hipotesis penelitian ini yang mengatakan bahwa "Pelatihan diversifikasi olahan hasil ikan dan pembinaan masyarakat berpengaruh positif terhadap minat berwirausaha di Desa Randegan Kulon Kecamatan Jatitujuh, Kabupaten Majalengka” dapat diterima atau secara simultan variabel pelatihan diversifikasi olahan hasil ikan dan pembinaan masyarakat mempunyai kemampuan untuk memprediksi minat berwirausaha. Kemampuan variabel pelatihan diversifikasi olahan hasil ikan dan pembinaan masyarakat memprediksi variabel minat berwirausaha yaitu sebesar84,7\% sedangkan sisanya 15,3\%ipengaruhi oleh faktor lain di luar penelitian ini.

Dengan diterimanya hipotesis satu $\left(\mathrm{H}_{1}\right)$ maka pelatihan diversifikasi olahan hasil ikan dan pembinaan masyarakat secara simultan atau bersama-sama memberikan pengaruh positif yang signifikan terhadap minat berwirausaha yang tergolong tinggi. Berdasarkan hasil yang diuraikan tersebut dan juga ditunjang oleh suatu kajian teori, bahwa tinggi rendahnya minat berwirausaha dipengaruhi oleh beberapa faktor antara lain yaitu faktor efikasi diri, faktor kebebasan bekerja, faktor visioner, faktor keahlian, faktor ketersediaan modal, faktor lingkungan sosial, faktor kontekstual danfaktor persepsi terhadap figur wirausahawan (Kadarsih et al., 2013). Hal tersebut sesuai dengan hasil penelitian yang dilakukan di Desa Randegan Kulon Kecamatan Jatitujuh Kabupaten Majalengka, bahwa tingginya minat berwirausaha pada responden dikarenakan adanya beberapa faktor intrinsik dan faktor ekstrinsik. Adapun faktor-faktor intrinsik yang mendorong adanya minat berwirausaha adalah efikasi diri (adanya keinginan, keyakinan, percaya diri terhadap kemampuan dirinya), memiliki keahlian atau keterampilan dan memiliki pengalaman dalam berdagang. 
Berdasarkan fakta di lapangan dan pertanyaan kuesioner yang mewakili indikator dari pelatihan keterampilan diversifikasi olahan hasil ikan terbukti bahwa masyarakat di Desa Randegan Kulon Kecamatan Jatitijuh Kabupaten Majalengka setelah mengikuti kegiatan pelatihan diversifikasi olahan ikan, responden mendapat ilmu pengetahuan baru, adanya perubahan pola pikir, adanya perubahan dalam hidup dan sebagian besar dari mereka memilki keahlian atau skill yang baru dalam membuat produk dari hasil pengolahan berbahan baku ikanseperti nuget ikan, penyedap rasa daging ikan dan bakso ikanyang dapatmeningkatkan minat dan motivasi peserta pelatihan dengan memanfaatkan potensi alam yang ada sehingga dapat meningkatkan perekonomian masyarakat desa. Hasil penelitian tersebut sejalan dengan hasil penelitian Irawati (2018), bahwa kegiatan pelatihan pada dasarnya dilaksanakan untuk menghasilkan perubahan tingkah laku dari orang-orang yang mengikuti pelatihan. Dengan adanya perubahan melalui pelatihan keterampilan kemudian masyarakat memiliki minat berwirausaha dan kedepannya akan lebih baik dengan memanfaatkan ilmu yang diperoleh dari pelatihan sebagai bekal berwirausaha.

Oleh karena itu kehidupan sejahtera akan lebih meningkat ketaraf yang lebih baik dan akan mengurangi jumlah pengangguran dengan menggunakan keahlian yang dimiliki sehingga mendapatkan keuntungan bagi diri sendiri serta kemajuan desa. Didukung dengan penelitian Irawati (2016), selain pelatihan, pembinaan terhadap usaha kecil harus dilakukan agar kegiatan usaha dapatberkembang menjadi lebih luas lagi. Usahakecil sebagai kegiatan ekonomi rakyat berskalakecil memiliki peran sentral dalamperekonomian Indonesia. Berdasarkan hasil penelitian yang dilakukan oleh Irawati (2016), terdapat hubungan yang kuat antara pelatihan dan pembinaan terhadap pengembangan usaha kecil dan dapat memberikan pengaruh yang cukup signifikan sebesar 57,6\%. Oleh karenanyaselain pelatihan keterampilan dibutuhkan sekali adanya pembinaan masyarakat yang merupakan faktor ekstrinsik untuk menumbuhkan dan meningkatkan minat berwirausaha. Berdasarkan hasil penelitian yang dilakukan oleh Kadarsih et al., (2013), bahwa dukungan akademik atau perguruan tinggi, dukungan dari pemerintah serta dukungan dari swasta melalui program-programkewirausahaan merupakan faktor kontekstual yang berpengaruh terhadap minat berwirausaha pada mahasiswa program studi

Diterbitkan oleh: 
pendidikan ekonomi Universitas Negeri Surakarta. Begitupula dengan penelitian yang dilakukan oleh Falaly dan Ilyas (2016), diperoleh hasil adanya peningkatan minat berwirausaha sebesar $10,52 \%$, akan tetapi peningkatan dari kegiatan pelatihan pembuatan sapu glagah belum menunjukkan perubahaan yang tinggi. Oleh karena itu perlu adanya kegiatan bimbingan dan pembinaan serta motivasi yang diselenggarakan oleh pemerintah maupun dari pihak swastakepada masyarakat yang telah mengikuti kegiatan pelatihandi Desa Gunungsari Kecamatan Pulosari Kabupaten Pemalang

Pembinaan masyarakat yang dilakukan oleh Fakultas Teknologi Kelautan dan Perikanan Universitas Nahdlatul Ulama Cirebon dan Penyuluh Perikanan Wilayah Jatitujuh Kabupaten Majalengka seagai upaya untuk menumbuhkan dan meningkatkan minat berwirausaha masyarakat di Desa Randegan Kulon Kecamatan Jatitujuh Kabupaten Majalengka terutama wirausaha olahan hasil ikan, dikarenakan bahan baku ikan yang tersedia di sekitar desa cukup banyak akan tetapi pengelolaan dan pemanfaatannya belum dikelola secara optimal. Kegiatan pembinaan tersebut terdiri dari upaya pendampingan, penyuluhan dan bimbingan yang dilakukan oleh akademisi dan pemerintah kepada masyarakat yang diawali dengan mendirikan dan menciptakan wirausaha baru, menumbuhkan dan mengembangkan kemampuan kapasitas usaha untuk meningkatkan omset penjualan. Menurut Irawati (2018) ; Alhempi dan Harianto (2013), menjelaskan bahwa pembinaan dan pengembangan usaha kecil dilakukan dengan cara-cara sebagai berikut: (1) Identifikasi potensi dan masalah yang dihadapi oleh usaha kecil, (2) Penyiapan program pembinaan dan pengembangan sesuai potensi dan masalah yang dihadapi oleh usaha kecil, (3) Pelaksanaan program pembinaan dan pengembangan, serta (4) Pemantauan dan pengendalian pelaksaan program pembinaan dan pengembangan bagi usaha kecil. Dengan demikian kegiatan pembinaan masyarakat secara tidak langsung akan sangat mempengaruhi minat berwirausaha seseorang karena adanya daya dukung lingkungan sosial yang akan membawa seseorang untuk membangun suatu jaringanyang dapat membantunya dalam prosesmemulai usaha seperti akses perizinan, akses permodalan, akses promosi dan akses pemasaran (Kadarsih et al., 2013). 


\section{KESIMPULAN}

Responden memiliki minat yang tinggi untuk berwirausaha sebanyak $74 \%$ setelah mengikuti kegiatan pelatihan diversifikasi olahan hasil ikan dan pembinaan masyarakat di Desa Randegan Kulon Kecamatan Jatitujuh Kabupaten Majalengka. Kondisi ini menunjukkan bahwa pelatihan diversifikasi olahan hasil ikan dan pembinaan masyarakat yang dilakukan oleh Fakultas Teknologi Kelautan dan Perikanan Universitas Nahdlatul Ulama Cirebon dan Penyuluh Perikanan Kecamatan Jatitujuh Kabupaten Majalengkamampu meningkatkan ketertarikan masyarakat produktif untuk melakukan kegiatan kewirausahaan. Didukung dengan analisis data statistik menggunakan uji regresi menghasilkan nilai koefisien determinasi sebesar 0,847 menunjukkan bahwa minat berwirausaha dijelaskan oleh pelatihan diversifikasi olahan hasil ikan dan pembinaan masyarakat sebesar $84,7 \%$, sedangkan sisanya 15,3\% dijelaskan oleh variabel lain yang tidak diteliti dalam penelitian ini seperti lingkungan kerja, lingkungan keluarga, persepsi terhadap figur wirausahawan dan lain-lain.

\section{DAFTAR PUSTAKA}

Alhempi, R. R dan W. Harianto. 2013. Pengaruh Pelatihan dan Pembinaan Terhadap Pengembangan Usaha Kecil Pada Program Kemitraan Bina Lingkungan. Jurnal Media Riset Bisnis dan Manajemen. Vol. 13 (1) : 20-38.

Eun, C. S., \& Resnick, B. G. (1985). Currency factor in international portfolio diversification. Columbia Journal of World Business, 20(2), 45-53

Eun, C. S., \& Janakiramanan, S. (1986). A model of international asset pricing with a c Elton, E. J., Gruber, M. J., Brown, S. J., \& Goetzmann, W. N. (2009). Modern portfolio theory and investment analysis. John Wiley \& Sons. onstraint on the foreign equity ownership. The Journal of Finance, 41(4), 897-914.

Frinces, Z.H. 2010. Pentingnya Profesi Wirausaha di Indonesia. Jurnal Ekonomi dan Pendidikan. Vol. 7 (1) : 34 -57.

Falaly, E.A \& Ilyas. 2016. Pengaruh Pelatihan Keterampilan Sapu Glagah Terhadap Minat Berwirausaha Pemuda Desa Gunungsari Kecamatan Pulosari Kabupaten Pemalang.Journal of Nonformal Education. Vol 2 (2) : 143-150.

Irawati, R. 2018. Pengaruh Pelatihan dan Pembinaan Terhadap Pengembangan Usaha Kecil. Jurnal JIBEKA. Vol. 12 (1) : 74-82. 
Kadarsih, R., Susilaningsih \& S. Sumaryati. 2013. Faktor-Faktor Yang Mempengaruhi Minat Berwirausaha Pada Mahasiswa Program Studi Pendidikan Ekonomi FKIP Universitas Negeri Surakarta. Jurnal Pendidikan Ekonomi UNS. Vol 2 (1) : 95-106.

Keputusan Menteri Kelautan dan Perikanan Republik Indonesia Nomor : KEP.14/MEN/2012 tentang Pedoman Umum Penumbuhan dan Pengembangan Kelembagaan Pelaku Utama Perikanan. 33 hlm.

Munawaroh, M., H. Rimiyati \& Fajarwati. 2016. Kewirausahaan. LP3M Universitas Muhamadiyah Yogyakarta, Gramasurya Yogyakarta. 164 hlm.

Rahmawati, F. 2008. Pengembangan Hasil Olahan Ikan Guna Meningkatkan Pendapatan Masyarakat Pesisir Pantai di Daerah Gunung Kidul. Seminar Nasional Hasil Penelitian Perikanan dan Kelautan Tahunan V : 1-5. Sosial Ekonomi Perikanan. Universitas Gadjah Mada. Yogyakarta.

Rusdiana, A. 2018. Kewirausahaan : Teori dan Praktik. CV Pustaka Setia. Bandung. $380 \mathrm{hlm}$.

Sugiyono. 2013. Metode Penelitian Kuantitatif, Kualitatif dan R\&D. CV Alfabeta. Bandung. $334 \mathrm{hlm}$.

Sujarweni, V.W. 2015. SPSS Untuk Penelitian. Pustaka Baru Press. Yogyakarta. 156 hlm.

Sukirman. 2017. Jiwa Kewirausahaan dan Nilai Kewirausahaan Meningkatkan Kemandirian Usaha Melalui Perilaku Kewirausahaan. Jurnal Ekonomi dan Bisnis. Vol. 20 (1) : 113-132. ISSN 1979 - 6471.

Diterbitkan oleh: 